\title{
Nitric oxide biosensor uncovers diminished ferrous iron-dependency of cultured cells adapted to physiological oxygen levels
}

\author{
Gulsah Sevimli \\ Sabanci University \\ Matthew Smith \\ King's College London \\ Tuba Akgul Caglar \\ Sabanci University \\ Şükriye Bilir \\ Istanbul Medipol University \\ Melike Secilmis \\ Sabanci University \\ Hamza Altun \\ Sabanci University

\section{Esra Yigit} \\ Gebze Technical University
}

\section{Fan Yang}

King's College London

\section{Roland Malli}

Medical University of Graz https://orcid.org/0000-0001-6327-8729

\section{Gürkan Öztürk}

Istanbul Medipol University

\section{Giovanni Mann}

King's College London

Emrah Eroglu ( $\square$ emrah.eroglu@sabanciuniv.edu )

Sabanci University https://orcid.org/0000-0002-9373-0808

\section{Article}

\section{Keywords:}

Posted Date: February 22nd, 2022

DOI: https://doi.org/10.21203/rs.3.rs-1381014/v1 
License: (c) (i) This work is licensed under a Creative Commons Attribution 4.0 International License. Read Full License 


\section{Abstract}

Iron is an essential metal for cellular metabolism and signaling, but it has adverse effects in excess. The physiological consequences of iron deficiency are well established, yet the relationship between iron supplementation and pericellular oxygen levels in cultured cells and their downstream effects on metalloproteins has been less explored. This study investigates the functionality of geNOps - an ironcontaining metalloprotein and NO biosensor - in cultured HEK293T epithelial and EA.hy926 endothelial cells adapted to standard room air $\left(18 \mathrm{kPa} \mathrm{O}_{2}\right)$ or physiological normoxia $\left(5 \mathrm{kPa} \mathrm{O}_{2}\right)$. We show that cells in culture require iron supplementation to activate the metalloprotein geNOps and demonstrate that cells adapted to physiological normoxia require significantly lower iron to achieve geNOps signals comparable to those measured in cells adapted to hyperoxia. This study establishes an essential role for recapitulating oxygen levels in vivo and uncovers a previously unrecognized requirement for ferrous iron supplementation under standard cell culture conditions to achieve geNOps functionality.

\section{Introduction}

Iron is an essential biometal with versatile biological functions and a key determinant of metalloproteins or enzyme cofactors responsible for electron transfer and catalysis ${ }^{1-4}$. Either lack or excess is detrimental to fundamental metabolism and signal transduction ${ }^{5-7}$. Thus, the regulation of iron metabolism is highly regulated in higher organisms ${ }^{8-10}$. However, delivery of sufficient and non-toxic concentrations of iron to cultured cells and the role of pericellular oxygen remains poorly investigated ${ }^{11,12}$.

Supplementation of culture media with animal or human sera containing transferrin is a common strategy to deliver iron to cultured cells ${ }^{13,14}$. Three traditional media are commercially available: supplemented with ferric nitrate, ferrous sulfate, or iron-free ${ }^{15}$. Importantly, ferrous iron is highly soluble at any $\mathrm{pH}$, while oxidized ferric iron at physiological $\mathrm{pH}$ without a transport protein or chelator is almost insoluble and poorly bioavailable ${ }^{16}$. Studies suggest that the iron concentration in the extracellular medium in vivo ranges within low micromolar levels while ascorbate concentrations can be as high as 1$5 \mathrm{mM}^{17}$. Notably, DMEM contains only $250 \mathrm{nM}$ ferric nitrate and neither ascorbate nor other reducing agents $^{18}$. Moreover, batch and supplier-dependent differences in sera ${ }^{19}$ critically affect iron concentration, oxidation, and reduction in cell culture media ${ }^{20}$.

Iron and oxygen are intimately linked and are critical cofactors in controlling biochemical pathways to sustain cellular redox balance, such as coordinating ferritin synthesis for iron storage and antioxidant responses ${ }^{21}$. Mammalian cells in vivo function under $1-13 \mathrm{kPa} \mathrm{O}_{2}$, dependent on the tissue or organ ${ }^{22}$ and, in the context of this study, renal epithelial and microvascular endothelial cells usually are exposed to $\sim 4-6 \mathrm{kPa} \mathrm{O}_{2}$ in vivo ${ }^{22}$. Notably, cells cultured under standard atmospheric $\mathrm{O}_{2}(\sim 18-21 \mathrm{kPa}$ at sea level) are exposed to hyperoxia, i.e., to sustained pro-oxidant stress that significantly alters their redox phenotype ${ }^{22}$. Although iron metabolism in cultured cells is most likely affected by ambient pericellular $\mathrm{O}_{2}$ 
levels, little is known about the relationship between ambient $\mathrm{O}_{2}$ and the functionality of metalloproteins in situ.

This study employs the genetically encoded biosensor geNOps ${ }^{23-25}$, a metalloprotein consisting of a non-heme iron cofactor required to sense intracellular $\mathrm{NO}$ dynamics ${ }^{26}$. Previous studies have shown that these informative biosensors only display full functionality (NO sensitivity) when cells expressing the probe were briefly treated with an iron(II) and ascorbate mixture before an imaging experiment $24,27,28$. We exploited this critical feature of geNOps to investigate its functionality in human embryonic kidney cells (HEK293T) and immortalized human umbilical vein endothelial cells (EA.hy926) under hyperoxic and normoxic cell culture conditions. Our study provides novel insights into the relationship between ambient $\mathrm{O}_{2}$, cellular iron uptake, and intracellular NO bioavailability.

\section{Material And Methods}

\section{Chemicals, buffers, and imaging media}

Dulbecco's modified Eagle's medium (DMEM), phenol-free DMEM, penicillin and streptomycin, trypsin, and fetal bovine serum (FBS) were purchased from Pan Biotech (Aidenbach, Germany). Cell culture supplements normocin were procured from Invivogen (Toulouse - France), hypoxanthine (HAT) supplements from LGC Standards (Istanbul, Turkey), transfection reagent Polyjet from Signagen (Maryland, USA), D-cysteine from ChemCruz (Heidelberg, Germany), L-Glutathione from AppliChem GmbH (Darmstadt, Germany), Hoechst 33342 from HelloBio (Bristol, UK), ferrozine-reagent from Sigma Aldrich (Taufkirchen, Germany) and FeRhoNox ${ }^{\mathrm{TM}}-1^{29}$ from Goryo Chemical (Sapporo, Japan). Unless stated otherwise, all other chemicals were purchased from neoFroxx (Einhausen, Germany).

Prior to imaging experiments, cells were incubated for $\sim 30 \mathrm{~min}$ at room temperature in a cell storage buffer consisting of $138 \mathrm{mM} \mathrm{NaCl}, 2 \mathrm{mM} \mathrm{CaCl}_{2}, 5 \mathrm{mM} \mathrm{KCl}, 1 \mathrm{mM} \mathrm{MgCl}_{2}, 1 \mathrm{mM} \mathrm{HEPES}, 2.6 \mathrm{mM} \mathrm{NaHCO}_{3}$, $0.44 \mathrm{mM} \mathrm{KH}_{2} \mathrm{PO}_{4}, 0.34 \mathrm{mM} \mathrm{Na}_{2} \mathrm{HPO}_{4}, 10 \mathrm{mM}$ D-glucose, $0.1 \%$ vitamins, $0.2 \%$ essential amino acids, and $1 \%$ penicillin/streptomycin, $\mathrm{pH}$ 7.4. In live-cell imaging experiments, HEPES-buffered physiological salt solution consisting of $138 \mathrm{mM} \mathrm{NaCl}, 5 \mathrm{mM} \mathrm{KCl}, 2 \mathrm{mM} \mathrm{CaCl}_{2}, 1 \mathrm{mM} \mathrm{MgCl} 2,10 \mathrm{mM}$ D-glucose, $10 \mathrm{mM}$ HEPES was prepared. All imaging buffers were adjusted to $\mathrm{pH} 7.4$ using $1 \mathrm{M} \mathrm{NaOH}$.

\section{Cell culture}

HEK293T were cultured in complete DMEM, containing $4.5 \mathrm{~g} / \mathrm{L}$ glucose, 10\% FBS, $100 \mu \mathrm{g} / \mathrm{ml}$ streptomycin, and $100 \mathrm{U} / \mathrm{ml}$ penicillin, in a humidified incubator $\left(37^{\circ} \mathrm{C}, 5 \% \mathrm{CO}_{2}\right)$. EA.hy 926 were cultured in complete DMEM containing $4.5 \mathrm{~g} / \mathrm{L}$ glucose and additional supplements: $2 \%$ HAT supplement (consisting of sodium hypoxanthine $(5 \mathrm{mM})$, aminopterin $(20 \mu \mathrm{M})$, and thymidine $(0.8 \mathrm{mM}))$ and 100 $\mu \mathrm{g} / \mathrm{ml}$ normocin. One day before transfection, cells were seeded $\left(\sim 3-5 \times 10^{5}\right.$ cells per well) on $30 \mathrm{~mm}$ glass coverslips No.1 (Glaswarenfabrik Karl Knecht Sondheim, Germany). At 80-90\% confluency, cells 
were transfected using PolyJet transfection reagent according to the manufacturer's instructions. All imaging experiments were performed 16-24 h after transfection.

\section{Iron supplementation procedure}

Equimolar concentrations ( $1 \mathrm{mM})$ of iron compound $\left(\mathrm{FeSO}_{4}, \mathrm{FeCl}_{2}\right.$, or iron(II) fumarate) and ascorbate in HEPES-buffered physiological salt solution were used to pretreat cells for 20 min at room temperature. Cells were washed twice with PBS to remove excessive iron(II) from cells and incubated in cell storage buffer for two hours prior to the imaging experiment. Due to the high stability and solubility, $\mathrm{FeSO}_{4} \mathrm{Was}$ used as an iron supplement in all experimental data shown.

\section{Stable cell line generation}

A cytosol-targeted O-geNOps (O-geNOp-NES) construct was subcloned into a 3rd generation lentivirus shuttle vector pLenti-MP2 (Addgene \#36097) using the following primers: forward 5'-

ATAGGATCCGCCACCATGGTGAGTGTG-3' including BamHI restriction site and reverse 5'ATAGTCGACTTACAAAGTCAATCTTTCT-3' including a stop codon and Sall restriction site. Stable EA.hy926 cell line generation was achieved following optimized protocols as recently described ${ }^{30}$. After positive transduction, cells were cultured for one week in fresh complete DMEM before fluorescence activated cell sorting (FACS). The top 30\% of O-geNOp-NES positive cells were selected by detecting red fluorescence emission using an excitation wavelength of $561 \mathrm{~nm}$ laser (Filter type: BP 593/40 nm) on a BD Influx Cell Sorter. EA.hy926 cells were sorted, and positively transduced cells were regularly maintained under cell culture conditions before imaging experiments. Stable EA.hy926 cells expressing 0geNOp-NES were seeded on $30 \mathrm{~mm}$ glass coverslips one day before an experiment.

\section{Real-time fluorescence imaging and high-resolution confocal microscopy}

Real-time cell imaging experiments were performed on inverted widefield epifluorescent microscopes, either an Axio Observer.Z1/7 or Axio Vert.A1 (Zeiss, Germany), equipped with a Plan-Apochromat 20x/0.8 dry objective, a Plan-Apochromat 40x/1.4 DIC (UV) VIR-IR oil immersion objective, and monochrome CCD cameras Axiocam 503. O-geNOp and HyPer7 expressing cells were imaged as described elsewhere $26,30,31$.

The intensity and number of cells stained with the labile iron turn-on fluorescent indicator FeRhoNox ${ }^{\mathrm{TM}}-1^{29}$ were collected and processed using Zen Blue 3.1 software (Zeiss, Germany). Intensity values in regions of interest were divided by cell numbers and normalized for all conditions. To evaluate cell viability, highresolution fluorescence and phase contrast confocal images were taken using a laser scanning confocal microscope LSM 800 (Zeiss, Germany), equipped with a Plan-Apochromat 20x/0.80 Ph 2 M27 objective. 2048 x 2048 image size pixels were selected, and averaging was set at 4 to obtain high-resolution images. Cells stained with propidium iodide were excited using a $561 \mathrm{~nm}$ laser, and respective emission light between 595-700 nm was collected using GaAsP-PMT. Hoechst labeled cells were excited using $405 \mathrm{~nm}$ laser light, and emission was collected using Multialkali-PMT between 410-546 nm. The 
detector gain, digital detector gain, and pinhole size for all channels were set to $650 \mathrm{~V}, 1$, and $35 \mu \mathrm{m}$, respectively. Phase-contrast images were taken using a photodiode detector.

\section{Intracellular iron imaging}

Hoechst and FeRhoNox ${ }^{\mathrm{TM}}-1^{29}$ co-imaging was performed in cells at $70-80 \%$ confluency. After cell treatment with $\mathrm{FeSO}_{4}$ and/or ascorbate, cells were stained with $5 \mu \mathrm{g} / \mathrm{ml} \mathrm{FeRhoNox}^{\mathrm{TM}}-1$ in physiological buffer (see above) for $60 \mathrm{~min}$ at $37^{\circ} \mathrm{C}$ and $5 \% \mathrm{CO}_{2}$. Subsequently, cells were washed with warm PBS and incubated for $15 \mathrm{~min}$ with $10 \mu \mathrm{g} / \mathrm{ml}$ Hoechst at $37^{\circ} \mathrm{C}$ and $5 \% \mathrm{CO}_{2}$. Cells were washed with warm PBS and incubated in a cell storage buffer before imaging.

Perls/Diaminobenzidine (DAB) staining of iron imaging was conducted, as previously described ${ }^{32}$. Cells were first fixed with Karnovsky fixative for $30 \mathrm{~min}$. Cells were imaged on a confocal light microscope LSM800, subsequently further treated with an epoxy embedding procedure to visualize the iron accumulation by electron microscopy. Cells were postfixed with $2 \%$ osmium tetroxide $\left(\mathrm{OsO}_{4}\right)\left(\right.$ Electron $^{2}$ Microscopy Sciences, PA, USA) for 30 min at room temperature followed by $2 \%$ uranyl acetate (Electron Microscopy Sciences, PA, USA) staining overnight at $4^{\circ} \mathrm{C}$. Following dehydration, cells were embedded in epoxy blocks. Epoxy blocks were trimmed and ultra-sectioned (100 nm) using an ultramicrotome (Leica EM UC7, Leica microsystems, Wetzler, Germany). Thin sections were observed under 3kV with the BSD detector of the GeminiSEM 500 electron microscope (Carl Zeiss, Jena, Germany).

To visualize intracellular iron accumulation, a scanning electron microscope with energy-dispersive X-ray spectroscopy (SEM/EDX) was used to obtain measurements of iron particles in cells. The same specimens were ultra-sectioned $(100 \mathrm{~nm})$ and used for EDX measurements. Measurements were done at 130,000x magnification and 2000 s scanning with 10kV EHT for carbon and iron atoms. For comparison, iron amounts were normalized to carbon in each selected region of interest.

\section{Cell viability and intracellular glutathione assays}

Propidium iodide (PI) and Hoechst staining were applied to identify dead cells and nuclei, respectively, using previously reported protocols ${ }^{33}$. Live cell imaging was performed on a laser scanning confocal microscope LSM 800 (Zeiss, Germany).

EA.hy926 and HEK293T cells were adapted to either 18 or $5 \mathrm{kPa} \mathrm{O_{2 }}$ for at least five days, reduced glutathione (GSH) extracted using 6.5\% trichloroacetic acid (Sigma-Aldrich, UK) and total GSH levels determined using a fluorometric assay ${ }^{33,34}$ in a CLARIOstar plate reader (BMG Labtech, Germany) and expressed $\mathrm{nmol} / \mathrm{mg}$ protein.

\section{Live-cell imaging under controlled oxygen conditions}

For experiments under physiological normoxia, cells were cultured in $\mathrm{O}_{2}$-regulated workstations (Scitive or InVivo 500, Baker-Ruskinn, U.S.A.) for at least 5 days with $\mathrm{O}_{2}$ maintained at $5 \mathrm{kPa} \mathrm{O}_{2}, \mathrm{CO}_{2}$ at $5 \%$ and $37^{\circ} \mathrm{C}^{35-38}$. This experimental procedure enables the cell redox proteome adaptation and avoids re- 
exposure of adapted cells to room air during trypsinization and/or treatments. An EVOS M7000 imaging system (Thermo Fisher Scientific, USA) was placed in the $\mathrm{O}_{2}$-regulated workstations for cell imaging. All imaging experiments were performed at 20x objective magnification (Olympus 20x super-Apochromat) using the 'RFP 2.0' LED light cube (Ex: 542/20 nm Em: 593/40 nm). Cells were washed with PBS and imaged in Earle's Balanced Salt Solution (EBSS) (Sigma-Aldrich, USA) with atmospheric $\mathrm{O}_{2}$ set to either 18 or $5 \mathrm{kPa}, \mathrm{CO}_{2} 5 \%$, and $37^{\circ} \mathrm{C}$. Analysis was performed using ImageJ software. An $\mathrm{O}_{2}$-regulated, timeresolved fluorescence plate reader (CLARIOstar, BMG Labtech, Germany) enabled measurements of OgeNOp-NES fluorescence under defined $\mathrm{O}_{2}$ conditions (see Fig. $5 \mathrm{c}, \mathrm{d}$ ). Cells adapted to either 18 or $5 \mathrm{kPa}$ $\mathrm{O}_{2}$ were seeded into clear bottomed 96 -well black plates and cultured for a further $48 \mathrm{~h}$. Cells were preincubated with the stated concentrations of $\mathrm{FeSO}_{4}$ and ascorbate before being washed with PBS and the addition of EBSS. Cells were incubated for a further hour before being transferred to the plate reader, preacclimatized to the correct $\mathrm{O}_{2}$ and $5 \% \mathrm{CO}_{2}$ at $37^{\circ} \mathrm{C}$. Fluorescent readings were taken at $12 \mathrm{~s}$ intervals at Ex: $532 / 25 \mathrm{~nm}$ and $\mathrm{Em}: 585 / 30 \mathrm{~nm}$. Treatments were delivered using the plate reader dual injection system at the stated times and concentrations.

\section{Statistical analysis}

All acquired imaging data were analyzed using GraphPad Prism software (GraphPad Software, San Diego, CA, USA). All experiments were repeated at least three times in different cell cultures. The number of experiments is given as ' $N$ ', and the total number of cells imaged are indicated as ' $n$.' For instance: 3/18 indicates $\mathrm{N}=3$ (triplicate cultures) and $\mathrm{n}=18$ (number of cells imaged in this experiment). Unless stated otherwise, all statistical data are presented as mean \pm SD in addition to the representative real-time traces shown as curves. Statistical comparison of two groups was evaluated using a two-tailed Student $t$-test. Statistical comparisons of multiple groups one-way ANOVA analyses of variances with post-test Dunnett (comparison of all pairs of columns to control) were performed. All single values for concentrationresponses were performed at least in triplicate.

\section{Results}

\section{Treatment with iron(II) and ascorbate is essential for geNOps functionality}

Standard cell culture settings under room air conditions $\left(18 \mathrm{kPa} \mathrm{O}_{2}\right)$ are unphysiological for most cell types; thus, we examined the effects of physiological $\mathrm{O}_{2}$ levels $(5 \mathrm{kPa})$ in HEK293T and EA.hy 926 cell lines stably expressing the orange variant of geNOps. Both cell lines adapted for five days to $18 \mathrm{kPaO} \mathrm{O}_{2}$ levels showed robust geNOps expression, while cells adapted to $5 \mathrm{kPa} \mathrm{O}_{2}$ displayed significantly lower basal fluorescence intensity (Fig. 1a-c \& e-g). Nevertheless, NOC-7, a potent NO donor ${ }^{23}$, evoked a robust geNOps signal in both cell lines adapted to physiological normoxia. In contrast, in cells adapted to standard culture under hyperoxia $\left(18 \mathrm{kPa} \mathrm{O}_{2}\right)$, geNOps displayed marginal changes in response to the potent NO donor. (Fig. 1d,h). Overall, these observations establish a critical role for physiological 
pericellular $\mathrm{O}_{2}$ in $\mathrm{NO}$ bioimaging, yet it remains unclear whether ambient $\mathrm{O}_{2}$ concentrations affect $\mathrm{NO}$ bioavailability ${ }^{39}$ or cellular iron(II) uptake and thereby geNOps activity.

Short-term (24 h) or long-term (21 days) culture of HEK293T cells under $18 \mathrm{kPa} \mathrm{O}_{2}$ in different commercially available media such as Dulbecco's Minimal Essential Media (DMEM), Advanced DMEM, F12, and F12K containing ferrous iron, ferric iron, or ascorbate, respectively, only led to marginal activation of geNOps (Supplementary Fig. 1). However, geNOps displayed full functionality upon treatment of cells with $1 \mathrm{mM} \mathrm{FeSO}_{4}$ and $1 \mathrm{mM}$ ascorbate for 20 min prior to imaging experiments (Supplementary Fig. 1). Long-term (14 days) adaptation of cells to sub-toxic concentrations of ascorbate (ranging from 12-96 $\mu \mathrm{M}$ ) or $\mathrm{FeSO}_{4}$ (ranging from 7-56 $\mu \mathrm{M}$ ) in DMEM also failed to activate geNOps (Supplementary Fig. 2). Overall, these data demonstrate that geNOps functionality requires cell treatment with media containing freshly prepared iron(II) and ascorbate before an imaging experiment.

\section{Imaging intracellular distribution of ferric and ferrous iron}

Our results so far demonstrate the requirement for iron(II) supplementation to cells to achieve full functionality of geNOps, yet the spatial distribution and quantification of the labile iron pool remain unclear. We initially performed high-resolution confocal imaging experiments using the fluorescent indicator FeRhoNox-1, a specific probe to detect cytosolic labile iron ${ }^{29}$. Collecting multiple focal planes in the Z-direction in HEK293T cells adapted to $18 \mathrm{kPa} \mathrm{O}{ }_{2}$ cells pretreated with $\mathrm{FeSO}_{4}$ and ascorbate revealed that a significant amount of the probe was also detectable on the surface of cells (Supplementary Fig. 3a). To further confirm whether iron(II) accumulates on the cell surface, we imaged cells stained with Perls and 3'-diaminobenzidine (DAB). Cells treated with ascorbate only were comparable to the control group. However, cells treated with $\mathrm{FeSO}_{4}$ in the absence of ascorbate displayed a remarkable accumulation of extracellular iron particles, indicating that most supplemented iron precipitates without entering the cells and aggregates on the surface of the cell membrane (Supplementary Fig. 3b).

In contrast, $\mathrm{FeSO}_{4}$ and ascorbate co-treatment led to negligible iron accumulation on the cell surface, whereas intracellular aggregates were detectable (Supplementary Fig. 3b). These results confirm that a strong reducing agent is essential to keep iron in solution reduced under hyperoxic conditions, allowing cells to internalize soluble iron from the culture media. FeRhoNox-1 imaging in cells adapted to either 5 or $18 \mathrm{kPa} \mathrm{O}_{2}$ and treated with $\mathrm{FeSO}_{4}$ only or in combination with ascorbate displayed higher levels of intracellular labile iron under physiological $\mathrm{O}_{2}$ conditions (Supplementary Fig. $3 \mathbf{c}, \mathbf{d}$ ), demonstrating the critical role of the redox state of iron in cellular uptake.

These results were further validated by electron microscopy (EM) (Fig. 2a). Correlative light and electron microscopy (CLEM) experiments confirmed the accumulation of extra- and intracellular iron. FeRhoNox-1 stained cells were less suitable for this protocol, as the chemical dye targets undefinable intracellular regions. Thus, we exploited Perls stained cells, intensified with diaminobenzidine (DAB), and then correlated high-resolution bright-field and EM images of the same cells (Fig. 2b,c). Our CLEM approach confirmed that cells treated with $\mathrm{FeSO}_{4}$ only displayed visible dark punctae, indicating the precipitation 
and accumulation of iron on the cell surface (Fig. 2b, left panel). These data correlate with EM images, confirming that ascorbate is required to internalize extracellular iron (Fig. 2b, right panel). Notably, there was an apparent accumulation around the endoplasmic reticulum (ER) without signs of ER stress (Fig.

\section{2c, right panel).}

\section{Optimization of the iron-supplementation procedure}

We next sought to optimize acute iron(II) supplementation by lowering the reducing agent and iron compound concentrations. Employing Taguchi guidelines ${ }^{40}$, we optimized all three parameters: $\mathrm{FeSO}_{4}$ and ascorbate concentrations and the incubation time (Supplementary Table 1). This approach established that a minimum concentration of iron(II) compound, reducing agent, and incubation time of $300 \mu \mathrm{M}, 500 \mu \mathrm{M}$, and $15 \mathrm{~min}$, respectively, is required to activate geNOps biosensors (Supplementary Fig. 4). As shown in Fig. 3a, the optimized iron supplementation protocol resulted in FeRhoNox-1 signals similar to those achieved by our initial iron loading protocol $\left(1 \mathrm{mM} \mathrm{FeSO}_{4}\right.$ and $1 \mathrm{mM}$ ascorbate for 20 $\mathrm{min})$. These results show that lower levels of $\mathrm{FeSO}_{4}$ and ascorbate provision under room air conditions yield similar levels of intracellular labile iron documented by geNOps functionality and FeRhoNox-1 (Fig. 3b).

Importantly, scanning electron microscopy with energy-dispersive X-ray spectroscopy (SEM/EDX) analysis for elemental identification and quantitative compositional information confirmed that optimized iron(II) concentrations did not lead to accumulation of intracellular iron(II) in undefinable structures (Fig. 3c, and Supplementary Fig. 5). Overall, our findings suggest that lower $\mathrm{FeSO}_{4}$ and ascorbate concentrations are sufficient and necessary to activate metalloprotein geNOps under standard cell culture conditions $\left(18 \mathrm{kPa} \mathrm{O}_{2}\right)$.

Cell viability and mitochondrial reactive oxygen species (ROS) generation were examined following acute iron(II) supplementation in HEK293T cells under $18 \mathrm{kPa} \mathrm{O}_{2}$. Cell viability and mitochondrial ROS levels remained unaffected by iron(II) supplementation (Fig. 4). However, treatment of HEK293T and EA.hy926 cells with $1 \mathrm{mM} \mathrm{FeSO}_{4}$ and $1 \mathrm{mM}$ ascorbate led to robust increases in mitochondrial $\mathrm{H}_{2} \mathrm{O}_{2}$ levels measured using the ultrasensitive $\mathrm{H}_{2} \mathrm{O}_{2}$ biosensor HyPer $7^{30,41}$ (Fig. 4c,d). Significantly, optimized iron(II) concentrations did not increase mitochondrial $\mathrm{H}_{2} \mathrm{O}_{2}$ levels $24 \mathrm{~h}$ after iron(II) supplementation (Fig. 4c,d). Basal intracellular GSH levels were lower in EA.hy926, but not in HEK293T cells adapted to $5 \mathrm{kPa}$ than cells adapted to $18 \mathrm{kPa} \mathrm{O}_{2}$, consistent with diminished oxidative stress in cells cultured under physiological normoxia ${ }^{36}$ (Supplementary Fig. 6a). Moreover, basal mitochondrial $\mathrm{H}_{2} \mathrm{O}_{2}$ levels in EA.hy 926 cells were comparable under $18 \mathrm{kPa}$ and $5 \mathrm{kPa}$, suggesting that mitochondrial ROS levels were affected negligibly by physiological normoxia (Supplementary Fig. 6c).

\section{The role of ambient oxygen levels on geNOps functionality in endothelial cells}

We next sought to examine the effects of optimized iron(II) supplementation in EA.hy926 endothelial cells capable of generating intracellular NO in response to the GPCR agonist adenosine triphosphate (ATP), 
which robustly triggers intracellular calcium mobilization to activate eNOS ${ }^{42}$ (Fig. 5a). Treatment of endothelial cells adapted to $18 \mathrm{kPaO}_{2}$ with ATP caused a robust intracellular geNOps signal (inhibitable by nitro-L-arginine methyl ester) in cells pretreated with the optimized iron(II) and ascorbate concentration. In contrast, the geNOps signal in non-iron treated cells was negligible (Fig. 5 b). Our results indicate that treating endothelial cells with iron(II) in combination with ascorbate is necessary for activating geNOps under standard hyperoxic culture conditions. We hypothesized that the iron(II) concentration could be lowered further by adapting endothelial cells to physiological normoxia $\left(5 \mathrm{kPa} \mathrm{O}_{2}\right)$ to mimic $\mathrm{O}_{2}$ levels in vivo ${ }^{22,38}$. EA.hy926 cells stably expressing O-geNOp-NES were adapted to either 18 or $5 \mathrm{kPa} \mathrm{O}$ for at least five days. We initially treated cells adapted to $5 \mathrm{kPa} \mathrm{O}_{2}$ with even lower iron(II) $\left(150 \mu \mathrm{M} \mathrm{FeSO}_{4}\right.$ and $300 \mu \mathrm{M}$ ascorbate). ATP stimulated NO production in these cells induced a robust geNOps signal that was diminished upon subsequent addition of the NO synthase inhibitor L-NAME (Fig. 5c). These results confirm our hypothesis that culturing endothelial cells under physiological normoxia requires treatment with significantly lower iron(II) and ascorbate concentrations. However, when EA.hy926 cells were adapted to standard cell culture hyperoxia $\left(18 \mathrm{kPa} \mathrm{O}_{2}\right)$ and pretreated with the same concentrations of iron(II) and ascorbate $\left(150 \mu \mathrm{M} \mathrm{FeSO}_{4}\right.$ and $300 \mu \mathrm{M}$ ascorbate), the geNOps signal in response to ATP was significantly decreased (Fig. 5d).

\section{Discussion}

The present study, investigating live-cell NO imaging in HEK293T and EA.hy926 cells, provides direct evidence that ambient $\mathrm{O}_{2}$ levels during cell culture critically affect: (i) ferrous iron uptake, (ii) metalloprotein functionality, and (iii) intracellular NO bioavailability. These findings highlight the importance of recapitulating oxygen levels encountered by cells and tissues in vivo and the necessity of iron(II) supplementation in cells cultured under physiological normoxia or standard hyperoxic culture conditions.

We employed a genetically encoded NO biosensor geNOps as a model system for a non-heme iron(II) containing metalloprotein in cultured cells ${ }^{23}$. A previous study demonstrated that geNOps functionality requires ferrous iron supplementation for optimal live-imaging of changes in intracellular NO levels ${ }^{28}$. We extended this experimental approach to probe the role of iron(II) supplementation and ambient oxygen levels on the functionality of the geNOps biosensor by exploiting the NO-sensitivity as a direct read-out for the probe's iron-dependent (dys)functionality.

Cells chronically exposed to hyperoxic $\mathrm{O}_{2}$ levels $\left(18 \mathrm{kPa} \mathrm{O}_{2}\right)$ showed a robust geNOps expression, yet the biosensor lacked sensitivity for exogenous NO administration (Fig. 1). Cells adapted to physiological normoxia $\left(5 \mathrm{kPa} \mathrm{O}_{2}\right.$ ) displayed lower basal fluorescence in both HEK293T and EA.hy 926 cells, as expected due to the requirement for $\mathrm{O}_{2}$ in the maturation of the fluorophore ${ }^{43}$. To our surprise, geNOps functionality was significantly improved under physiological $\mathrm{O}_{2}$ levels (Figs. 1 and 5), raising questions about whether $\mathrm{NO}$ bioavailability increased due to reduced scavenging of $\mathrm{NO}^{39}$ or whether iron(II) dependent biosensor activity was enhanced under physiological normoxia. In the context of the latter 
question, two well-established pathways regulate iron internalization in cultured cells: (i) ferric iron complex with serum protein transferrin and (ii) iron uptake via a divalent metal transporter (DMT1) ${ }^{44}$, or subtypes of transient receptor potential (TRP) channels ${ }^{45}$.

Notably, in cells adapted to different commercially available culture media containing ferric and/or ferrous iron supplemented with transferrin, the NO donor NOC-7 failed to activate geNOps functionality, probe sensitivity was recovered following brief treatment with fresh $\mathrm{FeSO}_{4}$ and/or ascorbate (Supplementary Fig. 1). These observations strongly suggest the oxidation of ascorbate and ferrous iron under room air conditions. We demonstrated that cell treatment with supraphysiological concentrations of ascorbate (but not GSH and cysteine (data not shown)) and ferrous iron for 20 min significantly enhanced the geNOps signal in cells adapted to $18 \mathrm{kPa} \mathrm{O}_{2}$. Interestingly, cell treatment with ascorbate alone only improved geNOps functionality marginally (Supplementary Fig. 1). This observation is critical and in line with previous reports ${ }^{46}$. In vitro studies show that different reducing agents, including flavin mononucleotide, ascorbate, sodium dithionite, and superoxide, cause reduction of the ferritin iron core and cause iron release ${ }^{46}$. The increased labile iron is available for iron(II)-chelating agents or proteins like geNOps (Fig. 6).

In contrast, other studies show that reductants such as glutathione poorly reduce ferritin ${ }^{47}$ and are less able to mobilize free iron, underpinning our findings that the reductants GSH and D-cysteine are less able to increase geNOps functionality (data not shown). Our results demonstrate that pretreatment of cells with ascorbate is suitable but not sufficient to gain geNOps functionality (Supplementary Fig. 1). These observations underpin the hypothesis that only a strong reducing agent can mobilize intracellular iron, as documented by the increase in geNOps signal (Supplementary Fig. 1). However, additional provision of ferrous iron further maximizes the functionality of metalloproteins. Thus, a reductive cytosolic and extracellular environment and iron(II) supplementation in culture media are essential to activate the nonheme iron containing metalloprotein geNOps fully.

Significantly, the FeRhoNox-1 signal in cells adapted to physiological normoxia ( $5 \mathrm{kPa}$ ) displayed the same levels of labile iron compared to cells adapted to hyperoxia (18 kPa) (Supplementary Fig. 3c,d). These findings may indicate that the cytosolic reductive/oxidative environment remains unaffected by pericellular oxygen levels, as evidenced in HEK293T cells, in which similar GSH levels were measured in cells adapted to 18 or $5 \mathrm{kPa} \mathrm{O}$ (Supplementary Fig. 6). Although both approaches (geNOps and FeRhoNox-1) document efficient iron(II) uptake following brief cell treatment with ferrous iron and ascorbate, the intracellular distribution of iron remained elusive. Accumulation of the FeRhoNox-1 probe to undefinable intracellular regions precluded us from identifying the labile iron pool with a cellular compartment. Correlative light and electron microscopy indeed showed that cell treatment with iron(II) only led to accumulation on the cell surface (Fig. 2). In contrast, in the presence of ascorbate, iron(II) no longer accumulated on the cell surface and appeared enclosed within undefinable structures surrounding the endoplasmic reticulum, presumably particles of excessive iron precipitated in lysosomal structures to be recycled. Importantly, treatment of cells with significantly lower iron(II) and ascorbate concentrations 
no longer caused intracellular accumulation of excessive iron particles, as evidenced by scanning EM and energy-dispersive X-ray spectroscopy (Fig. 3).

Although increases in the labile iron pool may have toxic effects due to the ability of iron to generate hydroxide $\left(\mathrm{OH}^{-}\right)$and hydroxyl radical (Fenton Reaction), ${ }^{48}$ imaging mitochondrial $\mathrm{H}_{2} \mathrm{O}_{2}$ levels confirmed that optimized iron(II) treatment ( $300 \mu \mathrm{M} \mathrm{FeSO}_{4}, 500 \mu \mathrm{M}$ ascorbate for $15 \mathrm{~min}$ ) did not increase $\mathrm{H}_{2} \mathrm{O}_{2}$ generation in cells transfected with HyPer7 (Fig. 4). Importantly, utilizing EA.hy926 cells stably expressing mitochondria-targeted HyPer7, we established that basal $\mathrm{H}_{2} \mathrm{O}_{2}$ levels were similar in cells adapted to 18 or $5 \mathrm{kPa} \mathrm{O}$ (Supplementary Fig. $6 \mathrm{c}$ ). These observations are critical, as it has been reported that cells shift their metabolism to reduced aerobic oxidative respiration under oxygen-poor conditions with a decreased electron transport rate, leading to collapse of mitochondrial membrane potential $\left(\Delta \psi_{m}\right)$ probably due to increased levels of mitochondrial ROS and enhanced NO formation ${ }^{39,49}$. Notably, cells adapted to physiological normoxia $\left(5 \mathrm{kPa} \mathrm{O}_{2}\right)$ required significantly lower iron(II) and ascorbate concentrations to achieve geNOps signals comparable to those measured in EA.hy926 cells adapted to standard room air culture conditions (Fig. 5).

In conclusion, cultured cells expressing the metalloprotein geNOps displayed marginal functionality when cultured under standard room air conditions, whilst geNOps sensitivity was enhanced following long-term culture under physiological normoxia. Our results further demonstrate that optimized iron(II) supplementation in vitro is required to achieve maximal functionality of geNOps and, most likely other metal-containing proteins (Fig. 6). Critically, our study raises an important caveat about interpreting biochemical activation and functionality of metal-containing enzymes in cells cultured under standard room air conditions. Given the caveats concerning chemical fluorescence probes ${ }^{50}$, further advances in novel genetic biosensors for high-resolution, real-time imaging of labile iron levels are warranted to enhance our understanding of iron-dependent metabolism and signaling pathways in cells under welldefined physiological oxygen levels ${ }^{51}$.

\section{Declarations}

\section{Acknowledgments}

We gratefully acknowledge support from Scientific and Technological Research Council of Turkey (Grant 118C242, E.E., T.A.C., H.Y.A., M.S., and G.S.), Integration Projects of Sabancı University EPD-2019-1 (Grant 118C242, E.E.), Heart Research U.K. (RG2673, G.E.M.), British Heart Foundation (FS/16/67/32548, G.E.M.) and King's Together Strategic Award (G.E.M.). We thank Professors Helmut Sies and Richard J. Naftalin for their helpful discussions.

\section{Author contributions}

G.E.M. and E.E. conceptualized the study; G.S., M.J.S., T.A.C., and Ş.B. developed the methodology; G.S., M.J.S., H.Y.A., M.S., T.A.C., Ş.B., F.Y., and E.N.Y. performed and analyzed the experiments; H.Y.A. and M.S. 
generated stable cell lines; G.S., T.A.C., M.J.S., G.E.M., and E.E. wrote the manuscript, which all authors reviewed. R.M. and G.Ö. provided reagents, equipment, and protocols. G.E.M. and E.E. are guarantors of this study, with responsibility for the integrity of the data and data analysis.

\section{Competing interests}

The authors declare no competing interests.

\section{Additional information}

Supplementary information. The online version contains supplementary material available at https://

Correspondence and request for materials should be addressed to:

Giovanni E. Mann or Emrah Eroglu

\section{References}

1. Rouault, T. A. Iron metabolism in the CNS: implications for neurodegenerative diseases. Nat Rev Neurosci 14, 551-564 (2013).

2. Crielaard, B. J., Lammers, T. \& Rivella, S. Targeting iron metabolism in drug discovery and delivery. Nat Rev Drug Discov 16, 400-423 (2017).

3. Torti, S. V. \& Torti, F. M. Iron and cancer: more ore to be mined. Nat Rev Cancer 13, 342-355 (2013).

4. Beard, J. L. Iron Biology in Immune Function, Muscle Metabolism and Neuronal Functioning. The Journal of Nutrition 131, 568S-580S (2001).

5. Stephenson, E., Nathoo, N., Mahjoub, Y., Dunn, J. F. \& Yong, V. W. Iron in multiple sclerosis: roles in neurodegeneration and repair. Nat Rev Neurol 10, 459-468 (2014).

6. van Swelm, R. P. L., Wetzels, J. F. M. \& Swinkels, D. W. The multifaceted role of iron in renal health and disease. Nat Rev Nephrol 16, 77-98 (2020).

7. Martines, A. M. F. et al. Iron metabolism in the pathogenesis of iron-induced kidney injury. Nat Rev Nephrol 9, 385-398 (2013).

8. Lane, D. J. R. et al. Cellular iron uptake, trafficking and metabolism: Key molecules and mechanisms and their roles in disease. Biochim Biophys Acta 1853, 1130-1144 (2015).

9. Wang, J. \& Pantopoulos, K. Regulation of cellular iron metabolism. Biochem J 434, 365-381 (2011).

10. Muckenthaler, M. U., Rivella, S., Hentze, M. W. \& Galy, B. A Red Carpet for Iron Metabolism. Cell 168, 344-361 (2017).

11. Halliwell, B. Cell culture, oxidative stress, and antioxidants: avoiding pitfalls. Biomed J 37, 99-105 (2014).

12. Recalcati, S., Gammella, E., Buratti, P. \& Cairo, G. Molecular regulation of cellular iron balance. IUBMB Life 69, 389-398 (2017). 
13. Arora, M. Cell Culture Media: A Review. Materials and Methods (2021).

14. Spasojević, I. What if cell culture media do not mimic in vivo redox settings? Redox Report 21, 127129 (2016).

15. Yao, T. \& Asayama, Y. Animal-cell culture media: History, characteristics, and current issues. Reprod Med Biol 16, 99-117 (2017).

16. Kosman, D. J. Iron metabolism in aerobes: managing ferric iron hydrolysis and ferrous iron autoxidation. Coord Chem Rev 257, 210-217 (2013).

17. Zhitkovich, A. Ascorbate: antioxidant and biochemical activities and their importance for in vitro models. Arch Toxicol 95, 3623-3631 (2021).

18. Ackermann, T. \& Tardito, S. Cell culture medium formulation and its implications in cancer metabolism. Trends Cancer 5, 329-332 (2019).

19. Fang, C.-Y., Wu, C.-C., Fang, C.-L., Chen, W.-Y. \& Chen, C.-L. Long-term growth comparison studies of FBS and FBS alternatives in six head and neck cell lines. PLoS One 12, e0178960 (2017).

20. Bogdan, A. R., Miyazawa, M., Hashimoto, K. \& Tsuji, Y. Regulators of Iron Homeostasis: New Players in Metabolism, Cell Death, and Disease. Trends Biochem Sci 41, 274-286 (2016).

21. Kerins, M. J. \& Ooi, A. The Roles of NRF2 in Modulating Cellular Iron Homeostasis. Antioxid Redox Signal 29, 1756-1773 (2018).

22. Keeley, T. P. \& Mann, G. E. Defining Physiological Normoxia for Improved Translation of Cell Physiology to Animal Models and Humans. Physiol. Rev. 99, 161-234 (2019).

23. Eroglu, E. et al. Development of novel FP-based probes for live-cell imaging of nitric oxide dynamics. Nature Communications 7, 10623 (2016).

24. Eroglu, E. et al. Real-time visualization of distinct nitric oxide generation of nitric oxide synthase isoforms in single cells. Nitric Oxide 70, 59-67 (2017).

25. Eroglu, E. et al. Genetic biosensors for imaging nitric oxide in single cells. Free Radical Biology and Medicine 128, 50-58 (2018).

26. Eroglu, E. et al. Real-Time Imaging of Nitric Oxide Signals in Individual Cells Using geNOps. in Nitric Oxide: Methods and Protocols (eds. Mengel, A. \& Lindermayr, C.) 23-34 (Springer, 2018). doi:10.1007/978-1-4939-7695-9_3.

27. Charoensin, S. et al. Intact mitochondrial $\mathrm{Ca} 2+$ uniport is essential for agonist-induced activation of endothelial nitric oxide synthase (eNOS). Free Radical Biology and Medicine 102, 248-259 (2017).

28. Eroglu, E. et al. Application of Genetically Encoded Fluorescent Nitric Oxide (NO) Probes, the geNOps, for Real-time Imaging of NO; Signals in Single Cells. JoVE 55486 (2017) doi:10.3791/55486.

29. Hirayama, T., Okuda, K. \& Nagasawa, H. A highly selective turn-on fluorescent probe for iron(II) to visualize labile iron in living cells. Chem. Sci. 4, 1250-1256 (2013).

30. Secilmis, M. et al. A Co-Culture-Based Multiparametric Imaging Technique to Dissect Local H2O2 Signals with Targeted HyPer7. Biosensors 11, 338 (2021). 
31. Eroglu, E., Saravi, S. S. S., Sorrentino, A., Steinhorn, B. \& Michel, T. Discordance between eNOS phosphorylation and activation revealed by multispectral imaging and chemogenetic methods. Proc Natl Acad Sci USA 116, 20210-20217 (2019).

32. Meguro, R. et al. Nonheme-iron histochemistry for light and electron microscopy: a historical, theoretical and technical review. Arch Histol Cytol 70, 1-19 (2007).

33. Pollack, A. \& Ciancio, G. Chapter 3 Cell Cycle Phase-Specific Analysis of Cell Viability Using Hoechst 33342 and Propidium lodide after Ethanol Preservation. in Methods in Cell Biology (eds.

Darzynkiewicz, Z. \& Crissman, H. A.) vol. 33 19-24 (Academic Press, 1990).

34. Hissin, P. J. \& Hilf, R. A fluorometric method for determination of oxidized and reduced glutathione in tissues. Anal Biochem 74, 214-226 (1976).

35. Keeley, T. P., Siow, R. C. M., Jacob, R. \& Mann, G. E. A PP2A-mediated feedback mechanism controls Ca2+-dependent NO synthesis under physiological oxygen. FASEB J 31, 5172-5183 (2017).

36. Warpsinski, G. et al. Nrf2-regulated redox signaling in brain endothelial cells adapted to physiological oxygen levels: Consequences for sulforaphane mediated protection against hypoxia-reoxygenation. Redox Biol 37, 101708 (2020).

37. Chapple, S. J. et al. Bach1 differentially regulates distinct Nrf2-dependent genes in human venous and coronary artery endothelial cells adapted to physiological oxygen levels. Free Radic. Biol. Med. 92, 152-162 (2016).

38. Chapple, S. J., Siow, R. C. M. \& Mann, G. E. Crosstalk between Nrf2 and the proteasome: therapeutic potential of Nrf2 inducers in vascular disease and aging. Int. J. Biochem. Cell Biol. 44, 1315-1320 (2012).

39. Hickok, J. R., Vasudevan, D., Jablonski, K. \& Thomas, D. D. Oxygen dependence of nitric oxidemediated signaling. Redox Biol 1, 203-209 (2013).

40. Rao, R. S., Kumar, C. G., Prakasham, R. S. \& Hobbs, P. J. The Taguchi methodology as a statistical tool for biotechnological applications: a critical appraisal. Biotechnol J 3, 510-523 (2008).

41. Pak, V. V. et al. Ultrasensitive Genetically Encoded Indicator for Hydrogen Peroxide Identifies Roles for the Oxidant in Cell Migration and Mitochondrial Function. Cell Metabolism 31, 642-653.e6 (2020).

42. Bogle, R. G., Coade, S. B., Moncada, S., Pearson, J. D. \& Mann, G. E. Bradykinin and ATP stimulate Larginine uptake and nitric oxide release in vascular endothelial cells. Biochem Biophys Res Commun 180, 926-932 (1991).

43. Chapagain, P. P., Regmi, C. K. \& Castillo, W. Fluorescent protein barrel fluctuations and oxygen diffusion pathways in mCherry. J Chem Phys 135, 235101 (2011).

44. Anderson, G. J. \& Vulpe, C. D. Mammalian iron transport. Cell Mol Life Sci 66, 3241-3261 (2009).

45. Nilius, B. \& Owsianik, G. The transient receptor potential family of ion channels. Genome Biology 12 , 218 (2011).

46. Bou-Abdallah, F., Paliakkara, J. J., Melman, G. \& Melman, A. Reductive Mobilization of Iron from Intact Ferritin: Mechanisms and Physiological Implication. Pharmaceuticals (Basel) 11, 120 (2018). 
47. Melman, G. et al. Iron release from ferritin by flavin nucleotides. Biochim Biophys Acta $1830,4669-$ 4674 (2013).

48. Merkofer, M., Kissner, R., Hider, R. C., Brunk, U. T. \& Koppenol, W. H. Fenton Chemistry and Iron Chelation under Physiologically Relevant Conditions: Electrochemistry and Kinetics. Chem. Res. Toxicol. 19, 1263-1269 (2006).

49. Stuart, J. A. et al. How Supraphysiological Oxygen Levels in Standard Cell Culture Affect OxygenConsuming Reactions. Oxid Med Cell Longev 2018, 8238459 (2018).

50. Ma, Y., Abbate, V. \& Hider, R. C. Iron-sensitive fluorescent probes: monitoring intracellular iron pools. Metallomics 7, 212-222 (2015).

51. Sies, H. et al. Defining roles of specific reactive oxygen species in cell biology and physiology. doi:https://doi.org/10.1038/ s41580-022-00456-z.

\section{Figures}
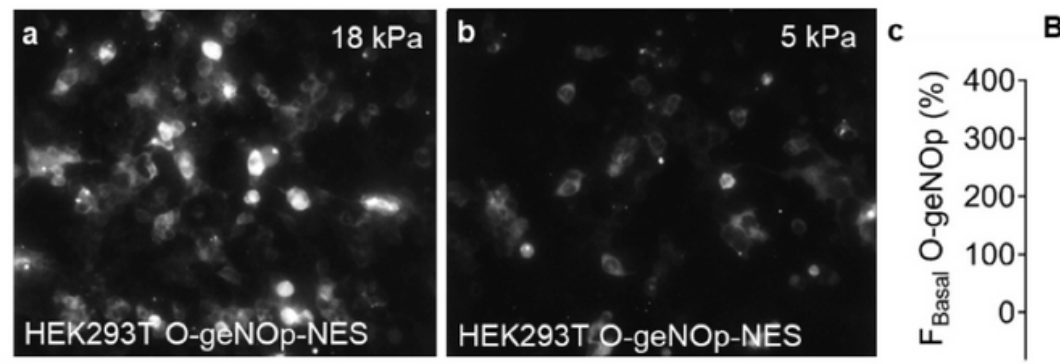

Basal Fluorescence
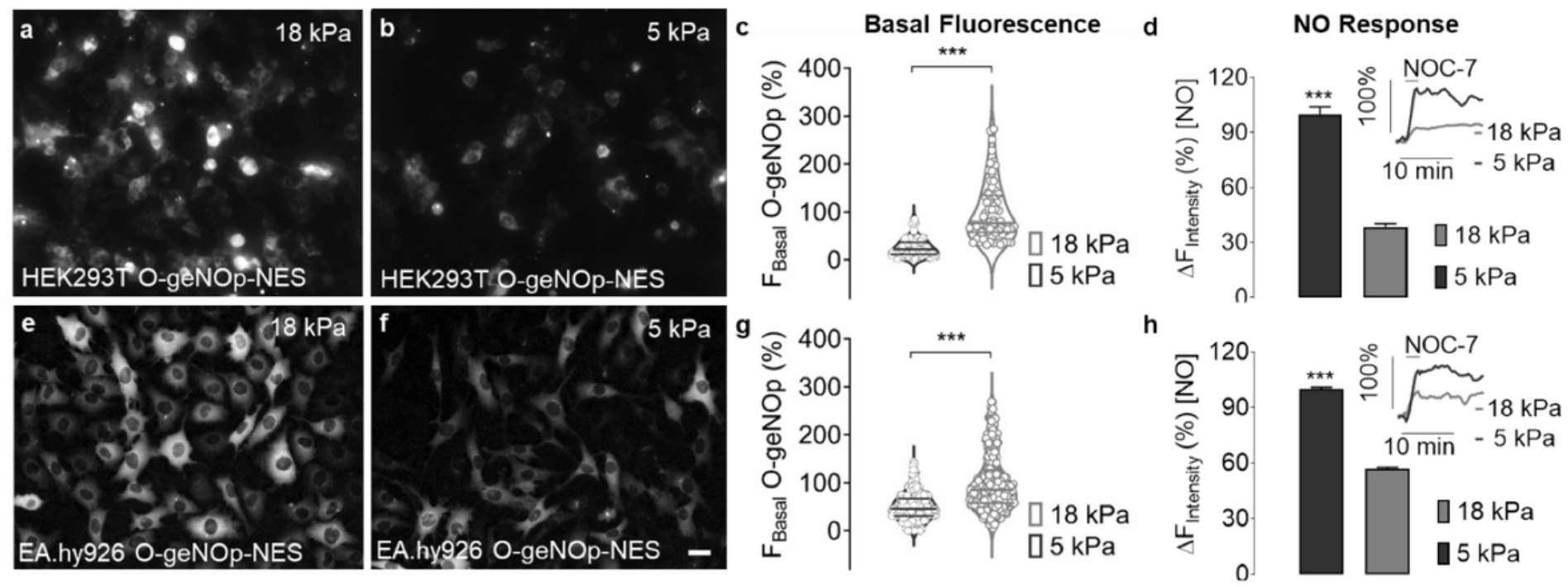

\section{Figure 1}

Effects of ambient oxygen levels on basal and NOC-7 induced geNOps responses in HEK293T and EA.hy926 cells. Representative widefield images of HEK293T cells stably expressing O-geNOp-NES adapted for five days to a, hyperoxic $(18 \mathrm{kPa})$ or $\mathbf{b}$, normoxic $(5 \mathrm{kPa}) \mathrm{O}_{2}$ levels. Scale bar represents 20 $\mu \mathrm{m}$. c, Violin plot shows the basal fluorescence intensity of O-geNOp-NES in HEK293T cells after adaptation to $18 \mathrm{kPa}$ (light grey dots, $\mathrm{n}=3 / 70$ ) or $5 \mathrm{kPa}$ (dark grey dots, $\mathrm{n}=3 / 73$ ) $\mathrm{O}_{2}$. d, Bar and inset show, respectively, maximum O-geNOp-NES response and representative real-time traces of NO in cells in response to $10 \mu \mathrm{M} \mathrm{NOC}-7$ after adaptation to $18 \mathrm{kPa}$ (light grey bar and curve, $\mathrm{n}=3 / 33$ ) or $5 \mathrm{kPa} \mathrm{O}_{2}$ (dark grey bar and curve, $n=3 / 34$ ). eh, Same experimental setup in EA.hy 926 cells as shown in the panels a-d. g, Violin plot shows the measurements of basal fluorescence intensity in EA.hy 926 cells after adaptation to $18 \mathrm{kPa}$ (light grey plot, $\mathrm{n}=3 / 327$ ) or $5 \mathrm{kPa}$ (dark grey plot, $\mathrm{n}=3 / 322) \mathrm{O}_{2} . \mathrm{h}$, Bars indicate maximum 0 - 
geNOp-NES signals in response to $10 \mu \mathrm{M}$ NOC-7 in EA.hy 926 cells adapted to $18 \mathrm{kPa}$ (light grey bar, $\mathrm{n}=3 / 40$ ) or $5 \mathrm{kPa}$ (dark grey bar, $\mathrm{n}=3 / 41) \mathrm{O}_{2}$. Insets show representative real-time traces of cells expressing 0-geNOp-NES adapted to $18 \mathrm{kPa}$ or $5 \mathrm{kPa} \mathrm{O}_{2}$ in response to $10 \mu \mathrm{M} \mathrm{NOC-7}$. Students $t$-test was applied for statistical analysis. All values denote mean \pm S.D., $\star \star \star ~ P<0.0001$.

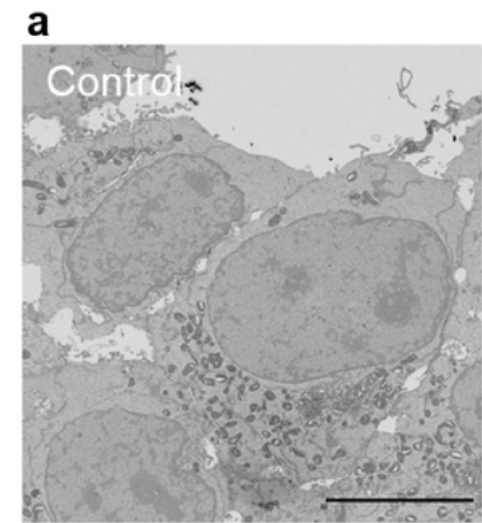

b
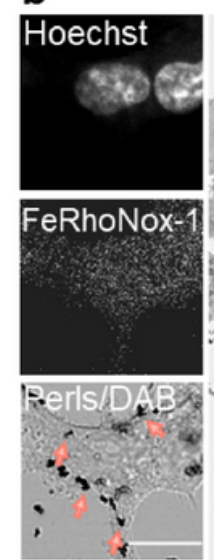
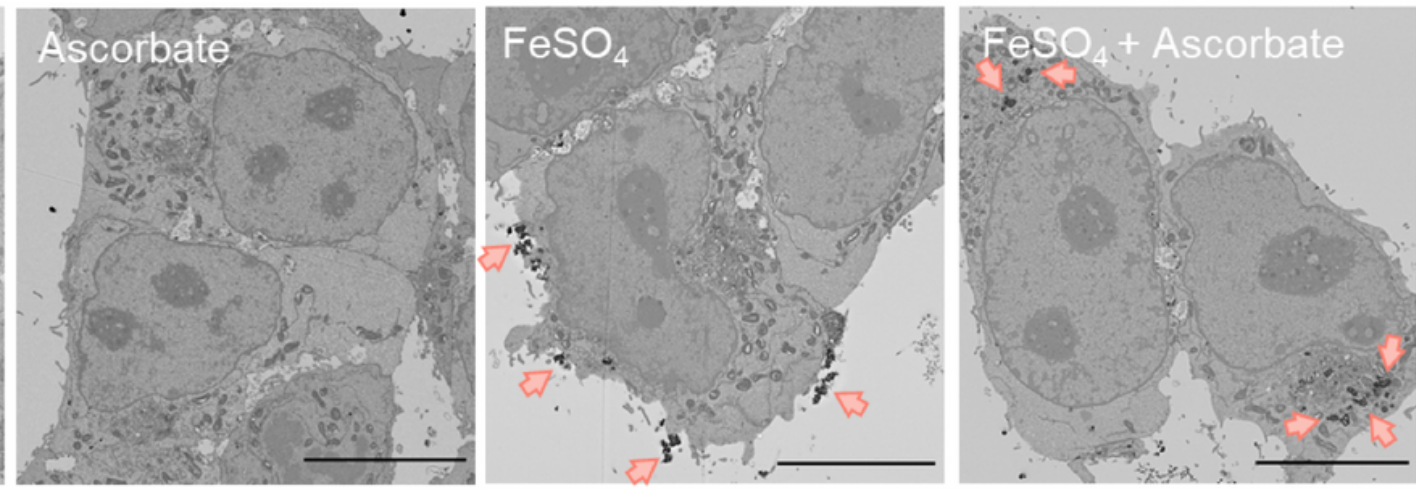

C

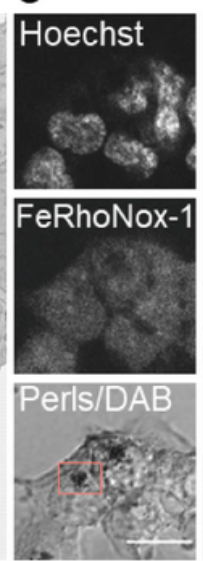

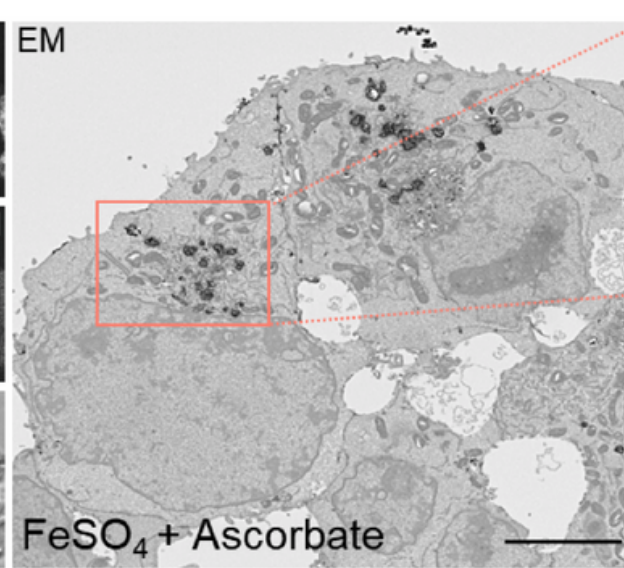

Figure 2

geNOps functionality correlates with cellular iron (II) uptake. a, Representative electron micrographs of HEK293T cells stained with Perls/DAB under control condition ( $1^{\text {st }}$ image), treated with $1 \mathrm{mM}$ ascorbate ( $2^{\text {nd }}$ image), treated with $1 \mathrm{mM} \mathrm{FeSO}_{4}$ ( $3^{\text {rd }}$ image), or treated with $1 \mathrm{mM} \mathrm{FeSO}_{4}+1 \mathrm{mM}$ ascorbate $\left(4^{\text {th }}\right.$ image). Pink arrows indicate accumulated iron particles. Scale bars indicate $10 \mu \mathrm{m}$. b, Representative low-magnification images of HEK293T cells stained with Hoechst, FeRhoNox-1, and Perls/DAB for CLEM experiments upon treatment with $1 \mathrm{mM} \mathrm{FeSO}_{4}$ for 20 min. c, Representative CLEM images of HEK293T cells following treatment with $1 \mathrm{mM}$ ascorbate $+1 \mathrm{mM} \mathrm{FeSO}_{4}$ for 20 min. Micrographs (pink bordered) show high magnification of the indicated region. The yellow lines indicate structures of the endoplasmic reticulum (ER). Scale bars of light microscopy images represent $15 \mu \mathrm{m}, 5 \mu \mathrm{m}$ for low magnification, and 2 $\mu \mathrm{m}$ for high magnification EM images. Representative data were selected from n=8-15 replicates. 

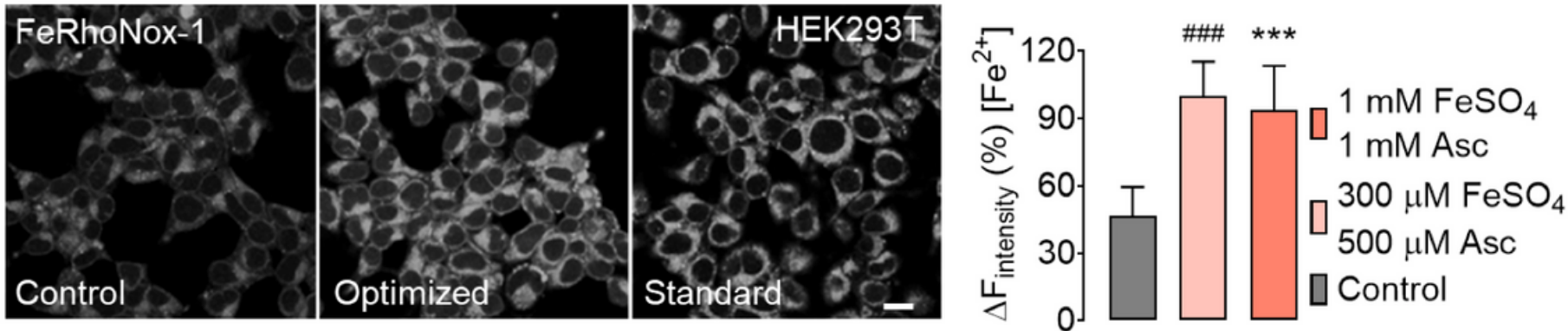

b
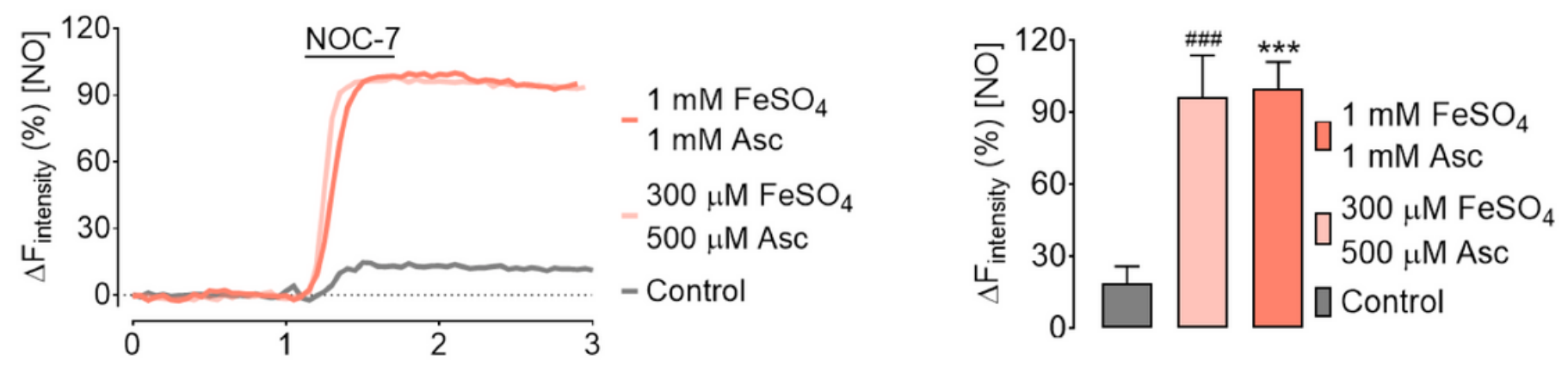

C

Time (min)
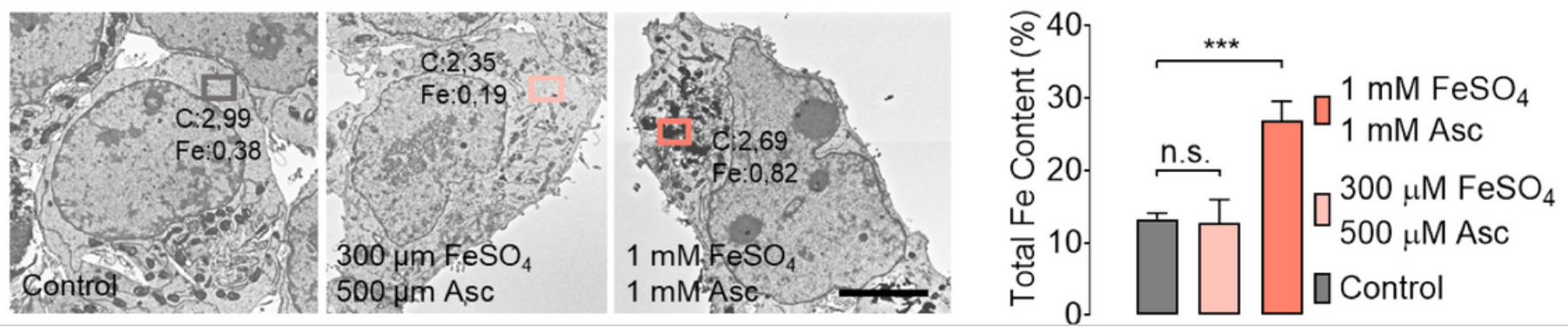

Figure 3

Optimization of iron (II) supplementation in HEK293T cells adapted to $18 \mathrm{KPa} \mathrm{O}_{2}$. a, Representative confocal images of HEK293T cells stained with FeRhoNox-1 under non-treated conditions (left image), treated with optimized iron (II) levels of $300 \mu \mathrm{M} \mathrm{FeSO}_{4}+500 \mu \mathrm{M}$ ascorbate for $15 \mathrm{~min}$ (middle image) and standard procedure $1 \mathrm{mM} \mathrm{FeSO}_{4}+1 \mathrm{mM}$ ascorbate for $20 \mathrm{~min}$ (right image). Bars show FeRhoNox-1 intensities under control conditions (grey bar, $\mathrm{n}=7 / 443$ ), optimized iron (II) concentration conditions (light pink bar, $n=10 / 469$ ), or standard iron (II) treatment conditions (pink bar, $n=11 / 511)$. b, Representative realtime traces of geNOps signals in HEK293T cells in response to $10 \mu \mathrm{M}$ NOC-7 (NO donor). Representative curves show NO signals in cells without iron (II) treatment (grey curve), with optimized iron (II) solution (light pink curve) and cells treated with the standard iron protocol (pink curve). Bars show respective maximum NO responses: control conditions; grey bar, $n=3 / 36$, optimized iron supplementation; light pink bar, $n=3 / 48$, and standard conditions; pink bar, $n=3 / 53$. $c$, Representative micrographs of SEM/EDX measurements in HEK293T cells untreated (left image), optimized iron supplementation (middle image), or treated with the standard iron protocol (right image). Bars represent total cellular iron content without (grey bar, n=3) or upon optimized (light pink bar, n=3) or standard iron(II) supplementation (pink bar, n=3). Dunnett's Multiple Comparison Test was applied to compare the total iron content following treatments 
relative to the control column. All values denote mean \pm S.D., $P<0.0001\left({ }^{\# \#}\right.$ Control vs $300 \mu \mathrm{M} \mathrm{FeSO}_{4}+$ $500 \mu \mathrm{M}$ ascorbate; ${ }^{* \star *}$ Control vs $1 \mathrm{mM} \mathrm{FeSO}_{4}+1 \mathrm{mM}$ ascorbate). Scale bar represents $5 \mu \mathrm{m}$.

a Propidium Iodide

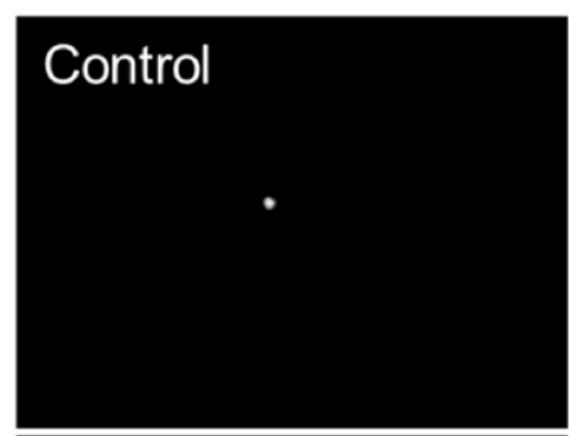

\section{Optimized}

-

\section{Standard}

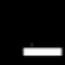

Hoechst
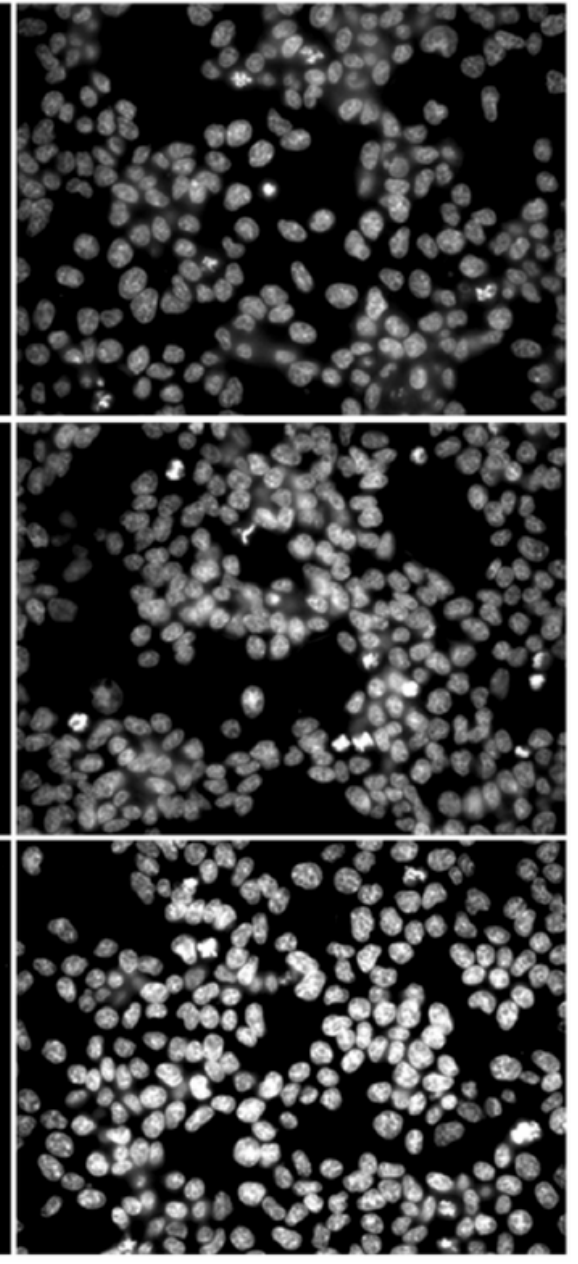

b

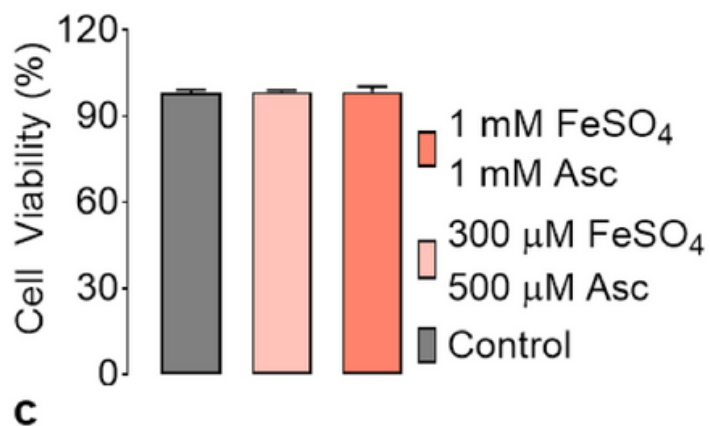

C

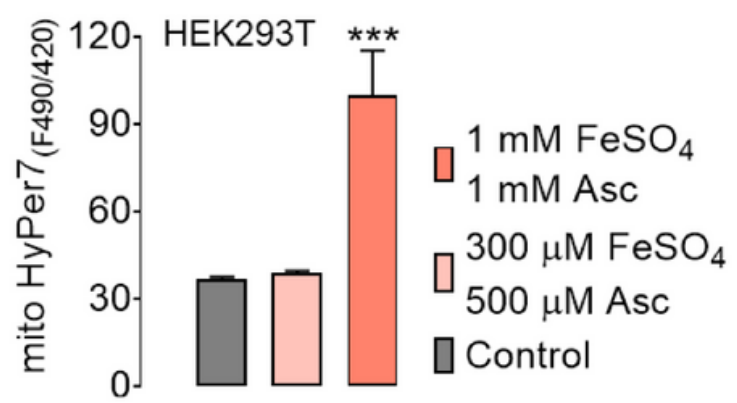

d

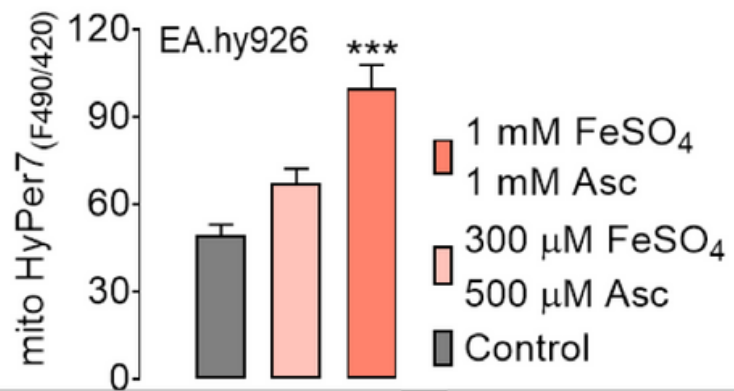

Figure 4

Analysis of cell toxicity and mitochondrial reactive oxygen species following iron(II) supplementation in HEK293T and/or EA.hy926 cells adapted to $18 \mathrm{kPa} \mathrm{O}_{2}$. a, Representative widefield images of HEK293T cells co-stained with propidium iodide and Hoechst under control conditions ( $\left.1^{\text {st }} \mathrm{row}\right)$, treated with 300 $\mu \mathrm{M} \mathrm{FeSO}_{4}+500 \mu \mathrm{M}$ ascorbate for $15 \mathrm{~min}$ ( $2^{\text {nd }}$ row), or treated with $1 \mathrm{mM} \mathrm{FeSO}_{4}+1 \mathrm{mM}$ ascorbate for 20 min ( $3^{\text {rd }}$ row). b, Bars represent cell viability under control conditions (grey bar, $\mathrm{n}=6 / 60$ ), $300 \mu \mathrm{M} \mathrm{FeSO}_{4}+$ $500 \mu \mathrm{M}$ ascorbate (light pink bar, $\mathrm{n}=6 / 60$ ), and $1 \mathrm{mM} \mathrm{FeSO}_{4}+1 \mathrm{mM}$ ascorbate (pink bar, $\mathrm{n}=6 / 60$ ). (c) Bars show basal HyPer7 ratio levels in mitochondria of HEK293T cells under control conditions (grey bar, $n=6 / 60$ ) and following acute treatment with $300 \mu \mathrm{M} \mathrm{FeSO}_{4}+500 \mu \mathrm{M}$ ascorbate (light pink bar, $\mathrm{n}=6 / 60$ ), or $1 \mathrm{mM} \mathrm{FeSO}_{4}+1 \mathrm{mM}$ ascorbate (pink bar, $\mathrm{n}=6 / 60$ ). $d$, Basal HyPer7 ratio levels in mitochondria of EA.hy 926 cells under control conditions (grey bar, $n=6 / 60$ ) and following acute treatment with $300 \mu \mathrm{M}$ $\mathrm{FeSO}_{4}+500 \mu \mathrm{M}$ ascorbate (light pink bar, $\mathrm{n}=6 / 60$ ), or $1 \mathrm{mM} \mathrm{FeSO}_{4}+1 \mathrm{mM}$ ascorbate (pink bar, $\mathrm{n}=6 / 60$ ). 
Dunnett's Multiple Comparison Test was applied to compare all treatments relative to the control column. All values denote mean \pm S.E.M., $P<0.0001$.
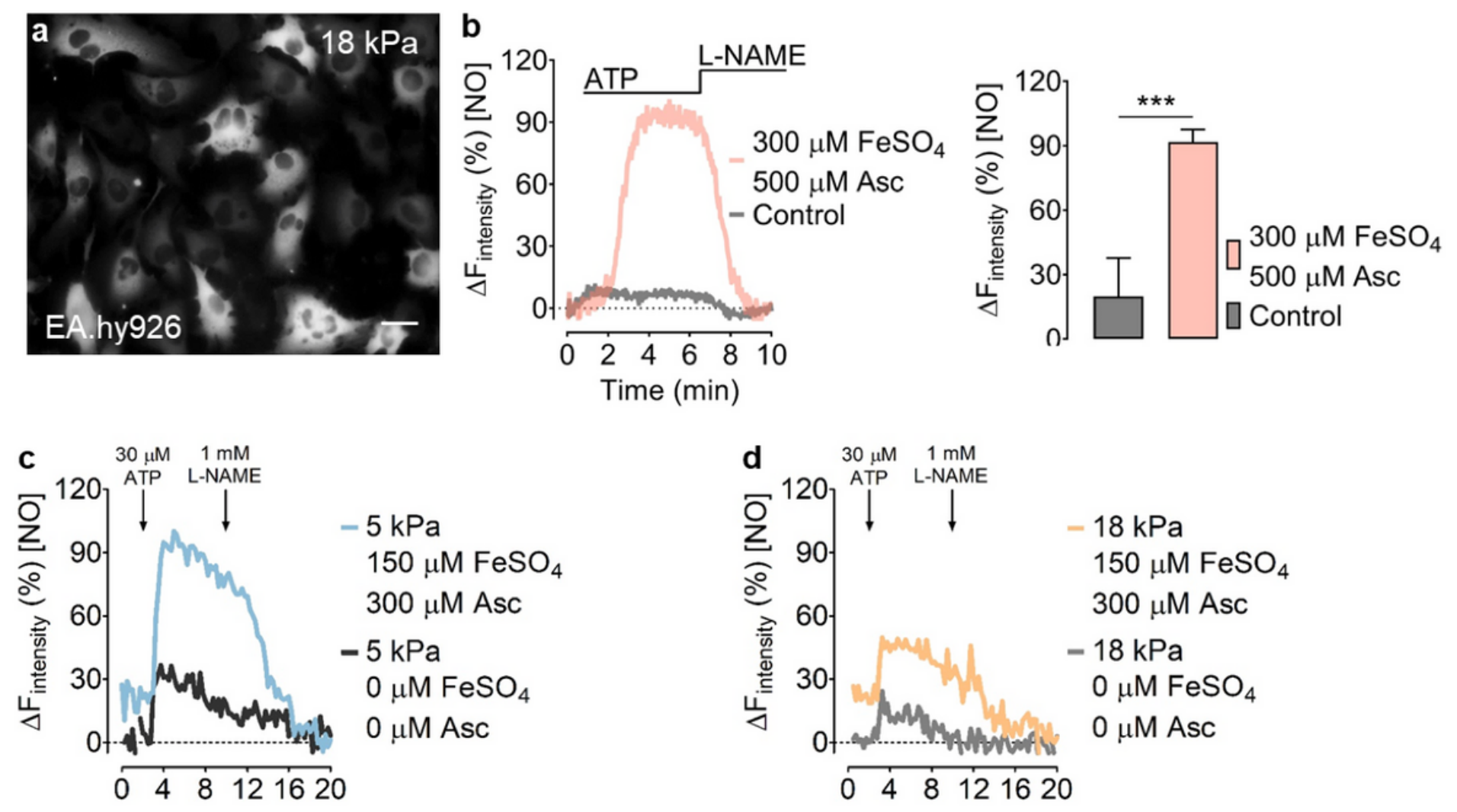

Time (min)
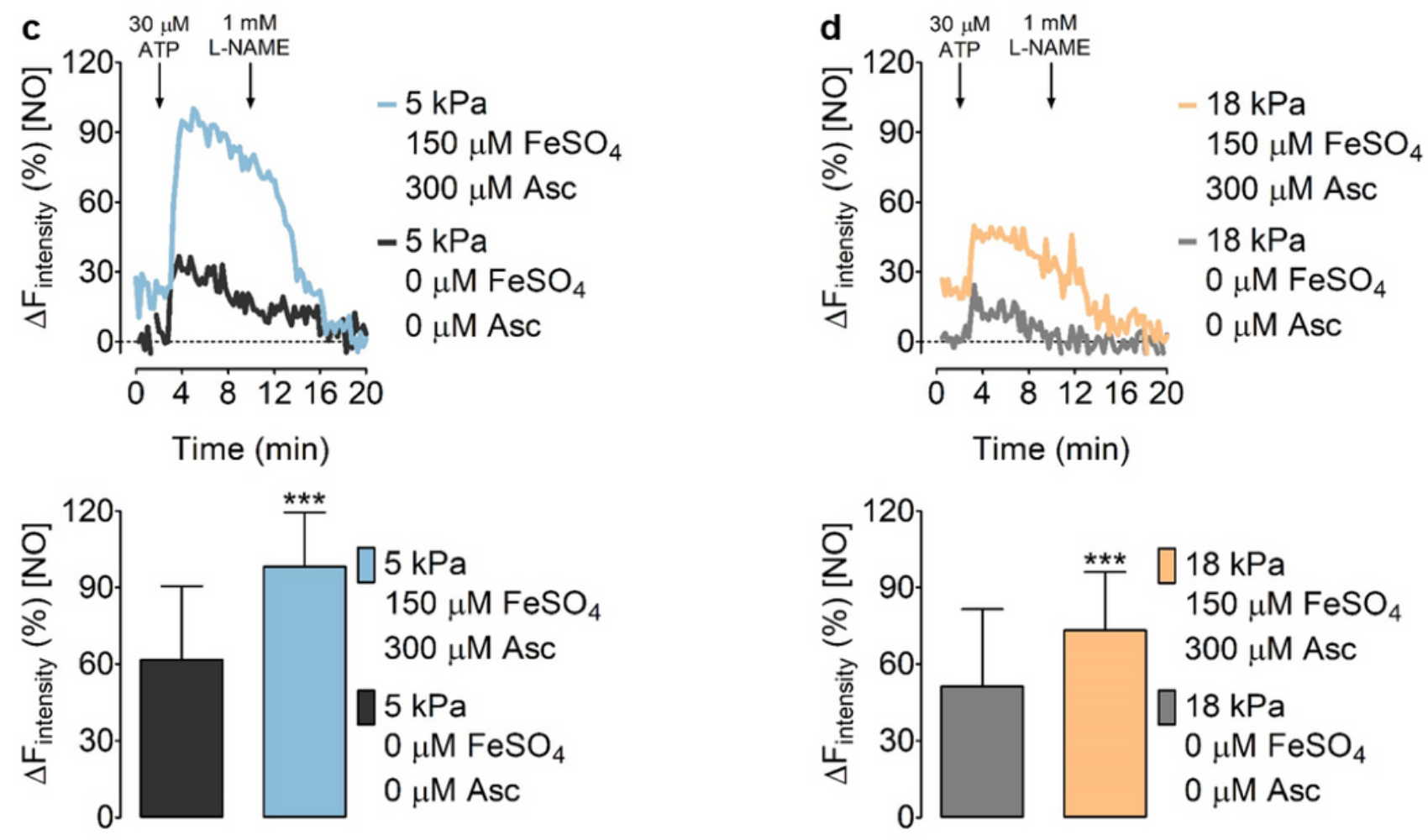

Figure 5

Visualizing intracellular NO signals in endothelial cells adapted to physiological normoxia or hyperoxia. a, Representative widefield image of EA.hy926 cells stably expressing O-geNOp-NES adapted to $18 \mathrm{kPa} \mathrm{O}_{2}$. b, Representative real-time traces of endogenous NO signals in EA.hy926 cells in response to $100 \mu \mathrm{M}$ ATP and subsequent administration of $500 \mu \mathrm{M} \mathrm{L-NAME}$ under control conditions (no iron treatment, grey curve, and bar, $n=3 / 54$ ) or pretreated with the optimized iron solution (pink curve and bar, $n=3 / 29$ ). c, Representative real-time traces show endogenous NO signals in EA.hy926 cells, expressing 0-geNOp-NES adapted to $5 \mathrm{kPaO}_{2}$. Cells were treated with $30 \mu \mathrm{M}$ ATP and subsequently with $1 \mathrm{mM} \mathrm{L-NAME}$. The blue curve shows cells pretreated with $150 \mu \mathrm{M} \mathrm{FeSO}_{4}+300 \mu \mathrm{M}$ ascorbate and the dark grey curve the NO response in cells without any treatment prior to imaging. Bars show maximum NO responses in cells 
without iron (II) treatment (dark grey bar, $\mathrm{n}=3 / 107$ ) or treatment with $150 \mu \mathrm{M} \mathrm{FeSO}{ }_{4}+300 \mu \mathrm{M}$ ascorbate (blue bar, $n=3 / 107$ ). d, Experiments were conducted with cells under the same treatment conditions shown in panel (c), but following adaptation of cells for five days to $18 \mathrm{kPa} \mathrm{O}_{2}$. Light grey curve and bars show NO responses with no iron (II) treatment $(n=3 / 107)$, and yellow curve and bars show NO responses in cells treated with $150 \mu \mathrm{M} \mathrm{FeSO}_{4}+300 \mu \mathrm{M}$ ascorbate ( $\left.\mathrm{n}=3 / 107\right)$. Student's $t$-test, was performed to determine statistical differences. All values denote mean \pm S.D., $\star \star \star ~ P<0.0001$.
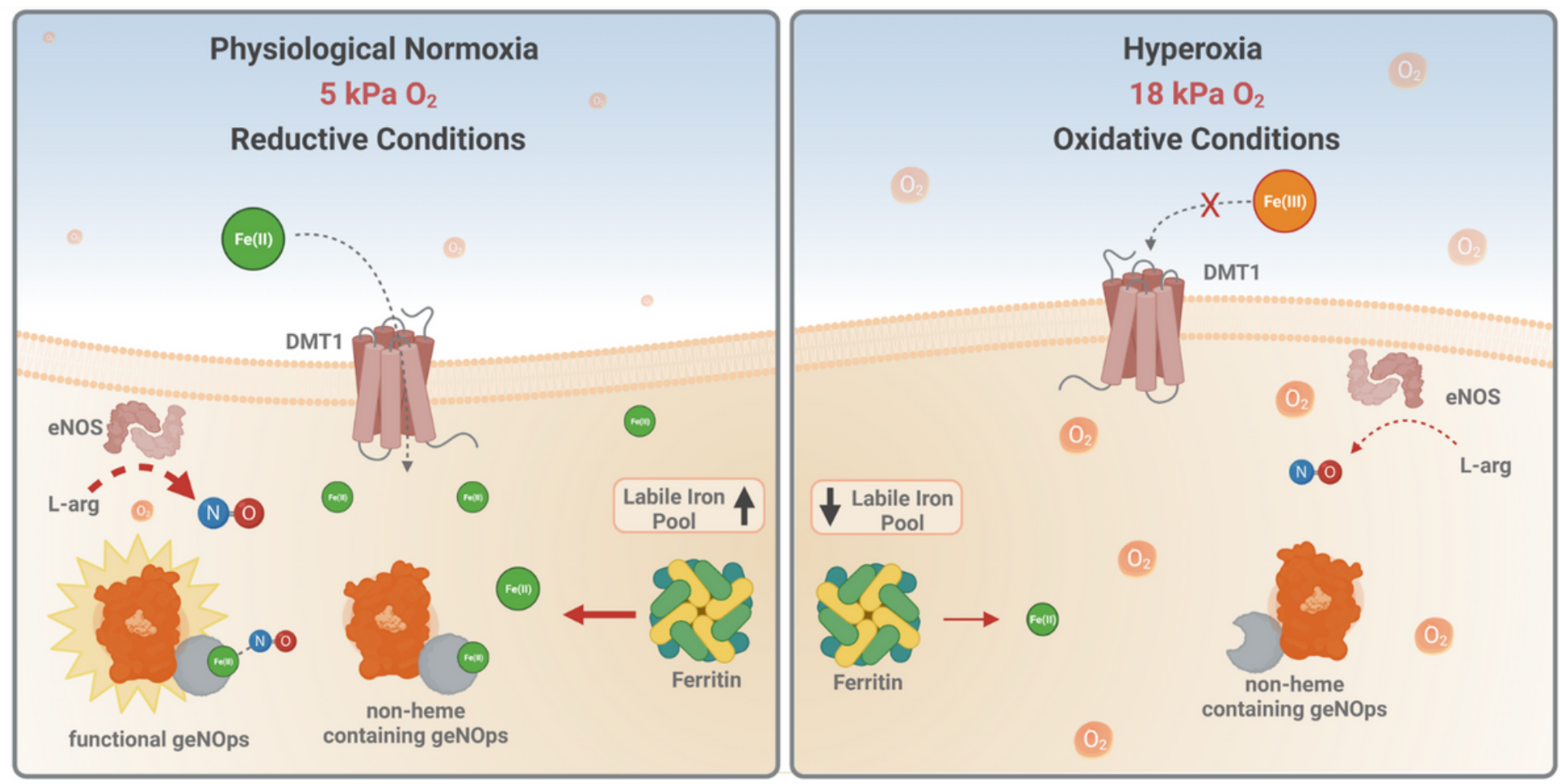

Figure 6

Schematic model for the role of pericellular oxygen on intracellular iron levels in cultured cells: This figure presents a model showing cellular iron uptake pathways presumably via divalent metal transporter channels (e.g., DMT1) under physiological normoxia (left panel, cells adapted to $5 \mathrm{kPa} \mathrm{O}_{2}$ for at least five days) and standard culture conditions (hyperoxia, room air (18 kPa), right panel) and its downstream effects on metalloprotein geNOps and NO bioavailability. We propose that cells under standard cell culture conditions lack a sufficient labile iron pool due to the rapid oxidation of ferrous iron to ferric iron in the culture media. Overall, our model highlights the importance of a cytosolic reduced environment and supplementation of sufficient ferrous iron(II) in the culture media to maximize the functionality of metalloproteins. See text for details.

\section{Supplementary Files}

This is a list of supplementary files associated with this preprint. Click to download.

- Supplementarydata.docx 
Page 22/22 